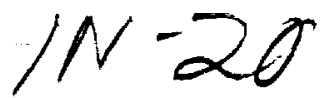

NASA Technical Memorandum 106178

AIAA-93-1886

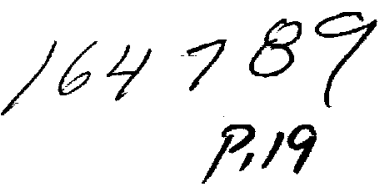

\title{
Reliability Studies of Integrated Modular Engine System Designs
}

Terry L. Hardy

National Aeronautics and Space Administration

Lewis Research Center

Cleveland, Ohio

and

Douglas C. Rapp

Sverdrup Technology, Inc.

Lewis Research Center Group

Cleveland, Ohio

Prepared for the

29th Joint Propulsion Conference and Exhibit

cosponsored by the AIAA, SAE, ASME, and ASEE

Monterey, California, June 28-30, 1993

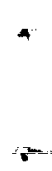

(NASA-TM-106178) RELIABILITY

STUDIES OF INTEGRATED MODULAR

ENGINE SYSTEM DESIGNS
(NASA)

$19 p$

\section{N93-27022}

Unclas 


\title{
RELIABILITY STUDIES OF INTEGRATED MODULAR ENGINE SYSTEM DESIGNS
}

\author{
Terry L. Hardy \\ National Aeronautics and Space Administration \\ Lewis Research Center \\ Cleveland, Ohio 44135 \\ and \\ Douglas C. Rapp \\ Sverdrup Technology, Inc. \\ Lewis Research Center Group \\ Brook Park, Ohio 44142
}

\begin{abstract}
A study was performed to evaluate the reliability of Integrated Modular Engine (IME) concepts. Comparisons were made between networked IME systems and non-networked discrete systems using expander cycle configurations. Both redundant and nonredundant systems were analyzed. Binomial approximation and Markov analysis techniques were employed to evaluate total system reliability. In addition, Failure Modes and Effects Analyses (FMEA), Preliminary Hazard Analyses (PHA), and Fault Tree Analysis (FTA) were performed to allow detailed evaluation of the IME concept. A discussion of these system reliability concepts is also presented.
\end{abstract}

\section{Introduction}

Integrated Modular Engine (IME) designs are currently being considered for use in various space propulsion applications. ${ }^{1-4}$ Conventional nonnetworked, or discrete, engines are designed such that each engine system is a standalone unit. In the discrete system, if a turbopump fails the corresponding thrust chamber must also be shut down. In the networked, or modular, engine concept, however, all turbopump assemblies and thrust chamber assemblies are joined by common manifolds. In this system, therefore, a turbopump or thrust chamber could be shut down independently should a failure occur in either component. Therefore, the IME offers potential advantages of increased fault tolerance and reliability when compared to discrete systems. The purpose of this report is to evaluate and compare the reliability of the IME and the discrete engine systems, to determine the reliability drivers of the IME, and to conduct a sensitivity study of the effects of component failures on system reliability of the IME.

Both quantitative and qualitative techniques were used to evaluate the IME reliability. The quantitative analyses consisted of binomial and Markov analyses. A binomial approximation technique was employed to characterize the reliability of the system based on component shutdown probabilities. Markov techniques were also used to evaluate the effects of engine burn duration on system reliability based on component failure rates. Because of the large uncertainty in the available component reliability data, the emphasis of the binomial approximation and Markov analyses was to conduct relative comparisons between modular and discrete systems, rather than to obtain absolute failure data. The qualitative techniques included Failure Modes and Effects Analyses (FMEA), Preliminary Hazard Analyses (PHA), and Fault Tree Analyses (FTA). An FMEA was conducted for the IME to determine the effects of single-point failures on the system. A PHA was used to identify potential hazards associated with the operation of the IME. Finally, an FTA was prepared to assist in the characterization of system-wide failures.

\section{System Description}

An Integrated Modular Engine system schematic is provided in Fig. 1. This design is based on a NASA Lewis Research Center effort to examine the IME concept and to determine methods of physically assembling such a system ${ }^{5}$. In this IME design an expander cycle configuration was used. As a baseline, eight thrust chamber assemblies are connected with four fuel and four oxygen turbopump assemblies. Five manifolds are required in this design to connect the thrust chambers and the turbopumps. Shutoff valves are used to isolate the pumps, turbines, and the thrust chambers in the event of a degradation of any of these components. The required number of valves for the IME is 66 , with 4 valves for each thrust chamber, fuel turbopump and oxidizer turbopump, plus 2 turbine bypass valves. Details of this IME design are provided in reference 5. By comparison, a discrete system, shown in Fig. 2, has no manifolds and 4 valves for each engine for a total of 32 valves.

\section{Analysis Techniques and Results}

Several quantitative and qualitative techniques 
were used to evaluate the reliability of the IME, including binomial approximation, Markov analysis, FMEA, PHA, and fault trees. A description of each process is included, and results for the above system configuration are provided for each of the techniques.

\section{Binomial Approximation}

In the binomial approximation technique, also known as the $k$-out-of- $N$ modeling technique, it is assumed that $k$ components out of a total of $N$ components must operate for the entire system to perform successfully. Therefore, the technique applies only to cases where redundancy is used. The following equation is used in the binomial approximation analysis of redundant systems: ${ }^{6}$

$$
R e_{\text {Total }}=R e^{N}+\sum_{\mathrm{x}=\mathrm{k}}^{\mathrm{N}-1} \frac{N !}{x !(N-x) !} \operatorname{Re}^{\mathrm{x}}(1-R e)^{N-x}
$$

where:

$\begin{array}{ll}\operatorname{Re}_{\text {Total }} & =\text { total system reliability }\left(1.0-\operatorname{Pr}_{\text {Total }}\right) \\ \operatorname{Re} & =\text { component reliability }(1.0-P r) \\ \operatorname{Pr}_{\text {Total }} & =\text { total system shutdown probability } \\ \operatorname{Pr} & =\text { component shutdown probability } \\ k & =\text { minimum number of components } \\ N & =\text { required for system operation } \\ N & \text { total number of components }\end{array}$

To analyze the IME system with redundancy, the reliability of each subsystem (fuel pump, oxidizer pump, fuel turbine, oxidizer turbine, thrust chamber) was obtained by multiplying the reliabilities of the components in each redundant subsystem (components in series). The total subsystem reliability was then obtained by using the binomial equation for the parallel subsystems. For instance, for the fuel turbopumps, $k=3$ and $N=4$ for the baseline case. The total system reliability was then obtained by multiplying the total subsystem reliabilities. For the discrete system the reliability of each engine was obtained by multiplying the reliabilities of each component. The binomial approximation was then used to obtain total system reliability $(k=7, N=8$ for the baseline case) for the parallel engine systems.

For the cases without redundancy, the part reliabilities can be multiplied to obtain a total system reliability, $R e_{\text {Total }}$. The total system failure probability is calculated in either case as $1.0-\operatorname{Pr}_{\text {Total }}$.

Tables I and II provide lists of components and their estimated failure rates for the IME and discrete systems, respectively. The failure rate is defined as the number of failures per 1000 firings (fir) for the binomial analysis. With the exception of the manifold estimates, these failure rates were obtained from reference 4 , where the Pratt \& Whitney Rocket Engine Reliability Database was used. This database takes into account historical engine failures based on flight data. Because of the limited amount of data available, a high degree of uncertainty associated with the failure rates can be expected. However, the use of the data does allow for relative comparisons between IME and discrete systems. The manifold failure rates are based on information from hydrogen and oxygen ducting. Again, a high degree of uncertainty is associated with these manifold failure rates. A sensitivity analysis was performed on the valve and manifold shutdown rates to determine the effects of these parameters on overall system reliability. Several key assumptions were used to formulate the analysis using the binomial distribution:

1. No partial failures are allowed; the only conditions are success and failure. The components are not repairable.

2. Only active redundancy is considered (i.e., all components are operating prior to the failure of any component).

3. No operating range concerns were included in the analysis (i.e., if one IME turbopump fails, it is assumed that the remaining turbopumps can meet the power requirement with no change in their reliability). Therefore, the failure rates were constant and independent of the number of components functioning.

4. The health monitoring system can identify and respond to a problem 100 percent of the time.

5. No common cause failures were included.

6. Sensor and controller reliabilities were not included in the analysis.

7. If a turbine (pump) failed on either the oxygen or hydrogen circuit the corresponding pump (turbine) would be deactivated.

8. Loss of a turbine bypass valve will lead to IME system loss (bypass simultaneously affects all turbines and adverse effects cannot be mitigated).

The binomial analysis was performed over a range of 2 to 12 thrusters. For the IME the number of turbopump assemblies was half the number of thrust chamber assemblies in each case. In addition, in the cases without redundancy the IME design did not include the isolation and check valves for the turbomachinery or for the nozzle coolant channel. These isolation and check valves would only be required for component isolation after failure; in the case without 
redundancy any component failure will cause total system failure and isolation would not be not necessary.

The results of the binomial approximation analysis are shown in Figs. 3 to 6 . Figure 3 compares the reliability of the IME with that of the discrete system for systems with 2 to 12 thrust chambers and where no redundancy is available (i.e., all components must operate). From the figure it can be seen that the discrete systems showed higher reliabilities than the IME systems for cases with less than six thrust chambers. For six thrust chambers and higher the IME proved to be more reliable than the discrete system. At low numbers of thrust chambers the manifold failure probability causes the IME system reliability to be reduced in comparison to the discrete system. As the number of thrust chambers is increased, the turbomachinery becomes a more important factor in the total system reliability. Because the IME has fewer turbopumps than the discrete system, the IME becomes more reliable than the discrete system as the number of thrust chambers and turbopump assemblies is increased.

Figure 4 shows a similar comparison assuming that the system has redundancy and can operate with one thrust chamber and one turbopump shutdown. In the case of the IME, this means that one turbopump and one thrust chamber could be shut down and the IME system would still meet the system thrust requirement; in the discrete system, if either a thrust chamber or turbopump was shutdown, one entire engine system could be shut down and the system would still meet the thrust requirement. It is apparent from a comparison of Figs. 3 and 4 that redundancy provides a significant benefit for both systems. Redundancy increases reliability by routing component failure to other operating components. As can be seen by Fig. 4 , the discrete system showed higher system reliabilities when compared to the IME. The discrete system showed reliabilities between 0.99998 and 0.99975 for 4 to 12 thrusters. These reliabilities corresponded to total system failure rates of 0.02 to 0.25 per 1000 firings. In contrast, the IME had reliabilities which varied from 0.99789 to 0.99773 , or failure rates of 2.11 to 2.27 per 1000 firings. Therefore, the system failure rates for the IME were approximately one order of magnitude higher than the discrete system.

From preliminary reliability studies not included in this report it appears that the reliability drivers are the valves and the manifolds, specifically because the turbine bypass valves and the manifolds represent the potential for single point failures. Therefore, sensitivity studies were performed on the reliabilities associated with these components. Figure 5 shows the effect of valve shutdown rate on system reliability for both the discrete and IME systems with eight thrust chamber assemblies. The valve failure rate (shutdown rate) was varied from 0 to 0.5 per 1000 firings. From the figure it can be seen that, even if the valves had a shutdown rate of 0 ( 100 percent reliability), the $\mathrm{IME}$ showed lower reliabilities than the discrete system. Because the turbine bypass valve represents a single point failure under the assumptions given previously, the analysis was also performed allowing redundancy in the bypass valves. Again, the discrete system showed higher reliabilities than the IME, but the reliability of both the discrete and IME systems did improve with the addition of redundancy. It should be noted that, because of the uncertainty in whether the loss of turbine bypass valves cause system failure, further analyses are required to determine the dependence of the system on these valves. However, this figure illustrates that, although the valve failure rate can affect the total system reliability, the valves do not appear to be the reason for reduced IME reliability in comparison to the discrete engine system.

Figure 6 shows the effect of manifold failure rate on total system reliability. From the figure it can be seen that the discrete engine concept provides higher reliabilities when compared to the IME concept except when manifold reliability was high and the turbine bypass valves were assumed to be redundant. The discrete system showed no change because no manifolds were assumed in this system. Examination of the design in Fig. 1 shows that the manifolds represent a single point failure, where loss of a manifold results in loss of the system. The manifolds would include the connections from the component piping (flanges, fasteners, etc.) as well as the ducting itself. Therefore, because the manifold has been shown to be the key reliability driver, it may be necessary to focus future efforts in IME design on manifold reliability, including connections, for the IME concept to achieve reliabilities similar to that of the discrete system.

The results of the binomial analysis show the significant improvement in system reliability derived from redundancy. Discrete systems increase reliability by isolating failures to the singular unit and reducing dependence on shared components, such as manifolds. Therefore, based on this analysis, the real reliability issue is not redundancy but the actual system design.

\section{Markoy Analysis}

Markov analysis techniques are useful tools in the reliability modeling of stochastic systems. ${ }^{6,7}$ To this end, a time-homogeneous Markov process with finite state space was used to compare the time-dependent reliability of IME and discrete engine system designs. Recording the degradation of system reliability with time proves useful in defining system operation envelopes based on demanded reliability and component failure rates. Furthermore, system reliability can be defined 
based on component integration and, to some extent, mutual component interaction for common cause analysis. The reliability results of $\mathrm{MME}$ and discrete engine system design concepts are presented subsequently. The initial discussion focuses on briefly introducing the Markov technique and assumptions employed. As in the binomial analysis, emphasis is centered on system sensitivity to component failure rates and not on the absolute magnitude of these rates.

The time-homogeneous Markov analysis technique determines a system's reliability over time based on the system's present operational condition (state). A state is defined as a given combination of failed and healthy components. A system state space comprises all states in which the system can occupy: an assumed initial no-failure state $\left(Z_{o}\right)$, single or multiple failed component state $\left(Z_{i}\right)$ and a final system failed state $\left(Z_{j}\right)$. A simple Markov state space is diagrammed in Fig. 7 . The system progresses in time from state $Z_{o}$, at time $t=0$, to other states within the finite state space. The transition probability, $p_{i, j}$, characterizes the likelihood of the system transitioning from any current state $Z_{i}$ to a new state, $Z_{j}$, in which a single system component has failed during discrete time interval $\delta t$. System state transition probability is directly proportional to the component failure rates and, in general, is only dependent on $\delta t$ (time-homogeneous).

The results of this type of analysis are insightful. As time progresses during system operation, the probability of system failure is determined by the rate at which its individual components fail and how their failure will impact the system. Increases in system failure probability during each successive time interval establishes a failure probability distribution. This probability distribution documents the temporal increase in system failure probability, and its difference from unity at each time step defines the system reliability $R e_{\text {sys }}$. Similarly, the mean time to failure $\left(\mathrm{MTTF}_{s}\right.$ ) (i.e., the expected time to system failure) may be determined from the distribution.

Unless noted otherwise, component failure rates were from reference 4 and are listed in Tables I and II. The components considered in these Markov analyses were the liquid oxygen turbopumps, liquid hydrogen turbopumps, thrust chamber assemblies and the manifolds, and turbine bypass valves. Each component failure rate is a composite of the failure rates of subassemblies that are considered to comprise the component. Thus, if any one component subassembly fails, the component itself failed.

Finally, some assumptions invoked in this Markov analysis follow:

1. All components are nonrepairable, actively redundant, load sharing, and, upon failure, fail completely (no partial failures). Load sharing implies that component failure rates are proportional to the load carried by the component.

2. For the IME design, the manifolds and turbine bypass valves were represented as single point failures.

3. When an $\mathbb{M E E}$ thrust chamber assembly fails, the thrust chamber assembly $180^{\circ}$ from the failed one is immediately shut down in order to maintain thrust balance. Hence, failing one thrust chamber assembly results in a net loss of two during a state transition.

4. System failure was assumed to occur when the system can no longer provide 100 percent thrust. IME system failure was defined as greater than one failed liquid oxygen turbopump assembly, greater than one failed liquid hydrogen turbopump assembly, greater than four shutdown thrust chamber assemblies (i.e., greater than two failed overall), and instantaneous failure with the single-point failures. Discrete system failure was defined as greater than four failed engines.

Figure 8 graphs the temporal decay of reliability of IME and discrete systems. At all system firing times, the discrete engine system had higher reliability than the IME system. The IME system demonstrated a 899-second $\mathrm{MTTF}_{s}$ in comparison to the discrete system with a 1964-second $\mathrm{MTTF}_{s}$. The reduced mean time to system failure of the IME was the result of, in part, system sensitivity of single point failures (manifolds, turbine bypass valves) and, in part, the intrinsically higher dependence of system operation on a smaller number of components. Likewise, at a demanded 99 percent reliability level, the discrete system could operate for 470 seconds longer than the IME system, from 500 seconds (discrete) to 30 seconds (IME). The capability of calculating acceptable firing durations based on component failure rates and demanded system reliability demonstrates the merit of the Markov analysis technique.

The IME system was found to be vulnerable to single point failures by the binomial analysis. Hence, the effect of assumed single point failure probability on IME system reliability was investigated by assuming failure-free ( 100 percent reliability) manifolds and turbine bypass valves (TBPVs) using Markov. System reliability improved as shown in Fig. 9. A dramatic improvement of 377 percent was achieved in firing duration ( 30 to 143 seconds) at 99 percent reliability when manifold/TBPV reliability is set to 1.0. Improvements in system firing time tapered off at lower reliability levels, indicating a decreasing importance of single- 
point failures with time. This point is expanded further subsequently. Note that these increases in firing duration, however large, were still less than the predicted firing durations of the discrete systems at all reliability levels.

Clearly, total system reliability is dependent on each component's failure rate. When a system's sensitivity to these rates is established, critical components that dictate system reliability are identified for reliability enhancement. A constant failure rate $(0.0003$ failures/ second) was imposed on all system components as a baseline. Each component's failure rate was then systematically doubled, and the resulting system reliability was compared with the baseline case.

With the noted exception of the manifolds/ TBPVs at a reliability level greater than 94 percent for the IME system, the turbopumps were the most critical components in determining reliability for all systems (discrete, IME). Figure 10 illustrates the reliability curve crossover of the manifold/TBPV with both the turbopumps and thrust chambers for the IME system. This crossover was due to both a faster rise and larger spread in the distribution of system failure probability due to doubling the manifold/TBPV failure rate. Also, the failure of thrust chamber assemblies was more significant for a discrete system than an IME system at the 99 percent reliability level. Firing durations decreased by 25 percent ( 247 to 186 seconds) in comparison to 3 percent (31 to 30 seconds) for the IME system. The results confirm the obvious fact that increasing component failure rates decrease system reliability.

Finally, the health monitoring system for all these analyses was assumed to instantly respond 100 percent of the time to component failure by shutting off and isolating the failed component. However, if an 80 percent effective health monitoring system assumption is used, then 20 percent of all component failures go undetected. Invoking this assumption, the reliability of the redundant IME system is instantaneously diminished, at each second, by 20 percent of the failures experienced by a nonredundant system (ref. 4 ). This assumes that allowing the failed component to operate does not cause catastrophic system failure. Figure 11 demonstrates an 80 percent reliable health monitoring system degrading reliability of the IME system. For example, system reliability decreased approximately 13 percent for a 500-second firing duration. This reliability decline increases with increasing firing duration until the system fails with 100 percent probability at approximately 1300 seconds.

\section{Eailure Modes and Effects Analysis}

$$
\text { A Failure Modes and Effects Analysis (FMEA) }
$$

is an inductive technique which provides a method for systematically identifying which parts can fail, how they fail, and what are the effects of the failures. Once the FMEA is completed, a Critical Items List (CIL) is prepared; the CIL provides a summary of the items which represent single point failures to the system. Generally, the FMEA is used as a qualitative approach, although the method can be used quantitatively by assigning failure probabilities for critical items and summing the individual probabilities. The advantages of using an FMEA analysis are that single point failures can be identified, and hazards can be identified on a piecepart level. The disadvantages of the FMEA lie in that, because the concentration is on individual failures of components, combined effects of coexisting failures (common cause failures) are not considered.

An FMEA was performed on the IME to identify component failure modes and their effects on the IME. Table III shows an example from this FMEA for the Oxidizer Pump Outlet Manifold, which includes the ducting and the connections to the manifold. Failure modes on manifolds include crack/fatigue failures, contamination in ducting and seals or sealing surfaces, seal failure, and fastener torque relaxation. Previous studies ${ }^{8}$ showed that leakage through flanges from fastener torque relaxation could present major problems in flight systems. Methods of mitigating this failure mode require investigation for the IME because of the large number of bolted flanges in this system. One option could be to incorporate all-welded connections to remove these failure modes; however, this design modification would reduce the ability to change out components prior to flight, thus reducing the flexibility of the IME. The CIL showed that the ignitor power supply failure, manifold failure, and valve actuator failure could be single point failures in the IME design.

\section{Preliminary Hazard Analysis}

A Preliminary Hazard Analysis (PHA) is a qualitative inductive method used to assess the potential hazards posed by the system. The PHA is usually prepared in conjunction with the FMEA. The objectives of the PHA are to identify the potential hazards within a system and to determine the significance of the potential accidents that might result from those hazards. Once identified, control measures are developed for each of the hazards. These hazard reduction control measures are, in the preferred order of application, as follows:

\section{Design change}

2. Engineered safety devices (e.g., redundant backups, relief valves, etc.)

3. Safety devices (e.g., guards, shields, personnel protection devices, etc.) 
4. Warning devices (e.g., alarms, lights, etc.)

\section{Procedures and training}

A PHA allows the qualitative identification of both the probability and severity of the risks in the system. Hazard probability and severity values are defined in reference 9 . However, the technique does not allow for identifying common cause failures and does not handle complex interactions in the system.

Table IV shows an example page from the PHA developed for the IME. The hazard considered here is fire or explosion in a manifold from leakage of propellants or from improper venting and routing of propellants. Control procedures include hardware safety factors, contamination control procedures, and leak checks prior to operation. Projectiles also were found to present a hazard to the manifold. Impact may cause cracking or a surface anomaly leading to a failure and the potential for loss of chambers or turbopumps. Control procedures for projectiles are similar to those described for the fire/explosion hazard.

\section{Eault Tree Analysis}

A Fault Tree Analysis (FTA) is a deductive failure analysis technique which identifies one top event and provides a method for determining the causes of that event. ${ }^{10}$ This approach differs significantly from those discussed previously in that the analyst postulates that the system has failed in some way and then attempts to determine all credible ways in which the undesired event can occur. The fault tree is a graphical model of the sequences of faults and failures that lead to the undesired event. Therefore, the fault tree represents the logical relationship between some basic events and the top event. The fault tree is a qualitative model of the events leading to failure which can be evaluated quantitatively. The quantitative evaluation of fault trees forms one of the core techniques in the probabilistic risk assessment (PRA) of nuclear power plants, ${ }^{11-13}$

Fault trees are especially attractive for large, complex systems such as the Integrated Modular Engine because of the following:

1. The pictorial display of the system provides insights into the failure consequence chains.

2. The relative effects of contributing factors to failure of the system can be identified quantitatively,

3. The weak points in the system can be quantitatively identified.

4. The vulnerability of the system to common cause failures can be readily identified.
Limitations to using a fault tree are that the analyst may not include all failure possibilities (errors of exclusion), there may be large uncertainty in the failure rate data, and the process can be extremely time-consuming. However, probabilistic techniques, including fault tree analyses, have been useful in assessing risk in many NASA applications. ${ }^{14}$

Figure 12 shows a sample page from the IME fault tree. The fault tree was prepared at NASA Lewis Research Center using the IRRAS code. IRRAS is a model developed for the U.S. Nuclear Regulatory Commission for the performance of probabilistic risk assessments. ${ }^{15}$ (The symbols used in the figure are defined in Fig. 13.) This fault tree did not include the failure of the turbine bypass valves due to the uncertainty associated with the system dependence on these components. From the figure the top level event is "Failure of IME to provide required thrust;" this event can occur if any of the second level events occur. Note that, if the "Failure of LH2 TPA/valves to provide flow" gate is examined, this second level event can occur if the turbopumps are lost or if the valve actuator pneumatic pressure is lost, assuming all the fuel turbopump valves operate using the same pneumatic pressure. According to the fault tree, then, common cause failure could occur such that all the valves are lost as a result of the pneumatic pressure loss. This illustrates the strength of the fault tree approach, the identification of common cause failures such as valve actuator failure identified in this analysis. The FTA also showed that a circuit malfunction in the ignitor power supply could represent a common cause failure if the ignitors of all the thrust chambers operate off the same power supply. It appears from an examination of the fault tree that the IME may be more susceptible to common cause failures than discrete systems.

In the nuclear industry, both reactor operating experience and PRA results consistently indicate that these common cause failures are major contributors to accidents. ${ }^{12}$ Reference 16 states that propulsion systems are inherently vulnerable to correlated (common cause) failures due to their high energy. Therefore, further efforts using quantitative probabilistic risk assessment techniques are required to determine the impact of common cause on the $\mathrm{IME}$.

\section{Concluding Remarks}

A study was conducted to evaluate the reliability of IME concepts. The reliability of the MME was compared to that of discrete engines using an expander cycle configuration. Binomial approximation techniques and Markov analyses were conducted to form this comparison. In addition, a Failure Modes and Effects Analysis, a Preliminary Hazard Analysis, and a Fault Tree 
Analysis were developed for the IME to determine the critical parameters and high risk components in the IME.

The results from the binomial approximation analysis showed quantitatively that the manifolds are the key reliability driver in the $\mathrm{IME}$, and that the $\mathrm{MME}$ requires low probability of manifold failure for the concept to show benefit compared to discrete systems. Therefore, from the analysis the IME will be a less reliable engine system than the discrete system in most cases, based on the assumptions and techniques used here. These results were confirmed by the Markov analysis. In addition, the Markov analysis showed that the IME had a lower mean time to system failure and a lower median failure time than the discrete engine system. The results of the Markov and binomial approximation techniques clearly show a significant improvement in system reliability derived from redundancy and designing rocket systems using independent engine units. Redundancy increases reliability by routing component failure to other operating components. Discrete engine systems increase reliability by isolating failures to the singular unit and reducing the dependence of engine functionality on shared components such as manifolds. Hence, based on this analysis, the real reliability issue is not redundancy but system integration (the system design itself). These analyses were performed on the basis of eight thrust chambers. Future systems may actually require fewer thrust chambers, depending on the mission chosen. Although the trends will be similar for fewer thrusters, future reliability studies will be required once the actual engine configuration is defined.

Failure Modes and Effects Analysis, Preliminary Hazard Analysis, and Fault Tree Analysis techniques were also used to assess the reliability of the Integrated Modular Engine concepts. All three techniques are necessary for a complete evaluation of a rocket engine system design. Future efforts should concentrate on quantitative fault tree analysis tradeoffs to improve the reliability of the IME, or any other rocket propulsion system considered for space applications.

\section{Acknowledgments}

The authors wish to acknowledge Michael Binder of Sverdrup Technology, Inc., and William Tabata of NASA Lewis Research Center for their assistance in preparing the analyses provided in this report. In addition, the authors wish to thank Randall Parsley and Theresa Ward of Pratt \& Whitney for their assistance in this effort.

\section{References}

1. Cramer, J.M.; and Wakefield, M.E.: Application of the Integrated Modular Engine (MME) to Space Vehicle Concepts. AIAA Paper 92-3692, 1992.

2. Pauckert, R.; and Harmon, T.: Integrated Modular Engine for Upper Stage Propulsion. AIAA Paper 923693, 1992.

3. Burkhardt, W.: Integrated Modular Engine Concepts for Space and Upper Stage Applications. AIAA Paper 92-3694, 1992.

4. Parsley, R.; and Ward, T.: Integrated Modular Engine Reliability Assessment. AIAA Paper 92-3695, 1992.

5. Frankenfield, B.: Fluid System Design Studies of Integrated Modular Engine System. to be published as AIAA Paper 93-1887, 1993.

6. Birolini, A.: On the Use of Stochastic Processes in Modeling Reliability Problems. Springer-Verlag, New York, 1985.

7. Dougherty, E.R., Probability and Statistics for the Engineering, Computing, and Physical Sciences. Prentice Hall, Englewood, NJ,1990.

8. MacGregor, C.A.: Reusable Rocket Engine Maintenance Study. NASA CR-165569, 1982.

9. System Safety Program Requirements. ML-STD882B, Mar. 30, 1984.

10. Vesely, W.E., et al.: Fault Tree Handbook. Report NUREG-0492, U.S. Nuclear Regulatory Commission, Washington, D.C., Jan. 1981.

11. Lewis, H.W.: Technological Risk. W.W. Norton, New York, 1990.

12. Wu, J.S.; and Apostolakis, G.E.: Experience with Probabilistic Risk Assessment in the Nuclear Power Industry, J.Hazard. Mater., vol. 29, no. 3, Feb. 1992, pp. 313-345.

13. Reactor Safety Study - An Assessment of Accident Risks in U.S. Commercial Nuclear Power Plants. Report WASH-1400 (NUREG-75/014), Office of Radiation Programs, Washington, D.C., Oct. 1975.

14. Buchbinder, B.: Risk Management for the Space Exploration Initiative, AIAA Paper 93-0377, 1993.

15. Russell, K.D., et al., Integrated Reliability and Risk Analysis system (IRRAS), Version 4.0. Report NUREG/CR-5813, EGG-2664, Office of Radiation Programs, Washington, D.C., Jan. 1992.

16. Fragola, J.R.; Booth, L.; and Shen, Y.: Current Launch Vehicle Practice and Data Base Summary Volume I. Report AL-TR-89-013, Air Force Astronautics Laboratory, June 1989. 
TABLE I, -INTEGRATED MODULAR ENGINE PARTS SUMMARY

\begin{tabular}{|c|c|c|c|c|c|}
\hline Subassembly & Component & $\begin{array}{l}\text { Number } \\
\text { in sed }\end{array}$ & $\begin{array}{c}\text { Total } \\
\text { vumber }\end{array}$ & $\begin{array}{l}\text { Part failure rale ( } \\
1000 \mathrm{sec}) \\
\text { (Markov) }\end{array}$ & $\begin{array}{c}\text { Part shutdown rate } \\
\text { (/1000 fir) } \\
\text { (Binomial) }\end{array}$ \\
\hline LOX pumps/turbines & $\begin{array}{l}\text { Turbine } \\
\text { Pump } \\
\text { Check valve } \\
\text { Shut-off valve } \\
\text { Pump exit line } \\
\text { Turbine inlet line } \\
\text { Turbine exit line }\end{array}$ & $\begin{array}{l}1 \\
1 \\
2 \\
2 \\
1 \\
1 \\
1\end{array}$ & $\begin{array}{l}4 \\
4 \\
8 \\
8 \\
4 \\
4 \\
4\end{array}$ & $\begin{array}{c}0.0175 \\
\bullet \\
0.0167 \\
0.0167 \\
0.0111 \\
0.0111 \\
0.0111 \\
\end{array}$ & $\begin{array}{c}0.1466 \\
* \\
0.2000 \\
0.2000 \\
0.0335 \\
0.0335 \\
0.0335 \\
\end{array}$ \\
\hline H2 pumps/turbines & $\begin{array}{l}\text { Turbine } \\
\text { Pump } \\
\text { Check valve } \\
\text { Shut-off valve } \\
\text { Pump exit line } \\
\text { Turbine inlet line } \\
\text { Turbine exit line }\end{array}$ & $\begin{array}{l}1 \\
1 \\
2 \\
2 \\
1 \\
1 \\
1\end{array}$ & $\begin{array}{l}4 \\
4 \\
8 \\
8 \\
4 \\
4 \\
4\end{array}$ & $\begin{array}{c}0.0194 \\
0.0167 \\
0.0167 \\
0.0334 \\
0.0334 \\
0.0111 \\
\end{array}$ & $\begin{array}{c}0.2419 \\
* \\
0.2000 \\
0.2000 \\
0.0835 \\
0.0835 \\
0.0835 \\
\end{array}$ \\
\hline $\begin{array}{l}\text { Combustion chamber/ } \\
\text { nozzle }\end{array}$ & $\begin{array}{l}\text { Ignitor } \\
\text { Injector } \\
\text { Comb. chamber } \\
\text { Nozzle } \\
\text { Check valve } \\
\text { Shut-off valve } \\
\text { Oxidizer line } \\
\text { Fuel line } \\
\text { Turbine inlet line } \\
\text { Coolant line } \\
\end{array}$ & $\begin{array}{l}1 \\
1 \\
1 \\
1 \\
1 \\
3 \\
1 \\
1 \\
1 \\
1 \\
\end{array}$ & $\begin{array}{c}8 \\
8 \\
8 \\
8 \\
8 \\
24 \\
8 \\
8 \\
8 \\
8 \\
\end{array}$ & $\begin{array}{l}0.0215 \\
0.0001 \\
0.1078 \\
0.0006 \\
0.0167 \\
0.0167 \\
0.0111 \\
0.0334 \\
0.0334 \\
0.0334 \\
\end{array}$ & $\begin{array}{l}0.0010 \\
0.0920 \\
0.1077 \\
0.1930 \\
0.2000 \\
0.2000 \\
0.0335 \\
0.0835 \\
0.0835 \\
0.0835 \\
\end{array}$ \\
\hline Manifolds, etc. & $\begin{array}{l}\text { LOX pump outlet } \\
\text { LH2 pump outlet } \\
\text { LOX turbine outlet } \\
\text { LOX turbine inlet } \\
\text { LH2 turbine inlet } \\
\text { Turbine bypass valves }\end{array}$ & $\begin{array}{l}1 \\
1 \\
1 \\
1 \\
1 \\
2\end{array}$ & $\begin{array}{l}1 \\
1 \\
1 \\
1 \\
1 \\
2\end{array}$ & $\begin{array}{l}0.0264 \\
0.0660 \\
0.0660 \\
0.0660 \\
0.0660 \\
0.0167 \\
\end{array}$ & $\begin{array}{l}0.1000 \\
0.5000 \\
0.5000 \\
0.5000 \\
0.5000 \\
0.2000 \\
\end{array}$ \\
\hline
\end{tabular}

TABLE II.- DISCRETE ENGINE PARTS SUMMARY

\begin{tabular}{|c|c|c|c|c|c|}
\hline Subassembly & Component & $\begin{array}{c}\text { Number } \\
\text { in set }\end{array}$ & $\begin{array}{l}\text { Total } \\
\text { number }\end{array}$ & $\begin{array}{l}\text { Part failure rate } \\
\text { (/1000 sec) } \\
\text { (Markov) }\end{array}$ & $\begin{array}{c}\text { Part shutdown rate } \\
\text { (/1000 fir) } \\
\text { (Binomial) }\end{array}$ \\
\hline LOX pumps/turbines & $\begin{array}{l}\text { Turbine } \\
\text { Pump } \\
\text { Control valve } \\
\end{array}$ & $\begin{array}{l}1 \\
1 \\
1\end{array}$ & $\begin{array}{l}8 \\
8 \\
8 \\
\end{array}$ & $\begin{array}{c}0.0175 \\
* \\
0.0167\end{array}$ & $\begin{array}{c}0.1466 \\
* \\
0.2000 \\
\end{array}$ \\
\hline LH2 pumps/turbines & $\begin{array}{l}\text { Turbine } \\
\text { Pump } \\
\text { Control valve } \\
\text { Main fuel valve } \\
\text { Pump exit line } \\
\text { Turbine inlet line } \\
\text { Turbine exit line }\end{array}$ & $\begin{array}{l}1 \\
1 \\
2 \\
1 \\
1 \\
1 \\
1\end{array}$ & $\begin{array}{c}8 \\
8 \\
16 \\
8 \\
8 \\
8 \\
8\end{array}$ & $\begin{array}{c}0.0194 \\
* \\
0.0167 \\
0.0167 \\
0.0334 \\
0.0334 \\
0.0111 \\
\end{array}$ & $\begin{array}{c}0.2419 \\
* \\
0.2000 \\
0.2000 \\
0.0835 \\
0.0835 \\
0.0835 \\
\end{array}$ \\
\hline $\begin{array}{l}\text { Combustion chamber/ } \\
\text { nozzle }\end{array}$ & $\begin{array}{l}\text { Ignitor } \\
\text { Injector } \\
\text { Comb. chamber } \\
\text { Nozzle } \\
\text { Oxidizer line } \\
\text { Fuel line } \\
\end{array}$ & $\begin{array}{l}1 \\
1 \\
1 \\
1 \\
1 \\
1\end{array}$ & $\begin{array}{l}8 \\
8 \\
8 \\
8 \\
8 \\
8\end{array}$ & $\begin{array}{l}0.0215 \\
0.0001 \\
0.1078 \\
0.0006 \\
0.0111 \\
0.0334 \\
\end{array}$ & $\begin{array}{l}0.0010 \\
0.0920 \\
0.1077 \\
0.1930 \\
0.0335 \\
0.0835 \\
\end{array}$ \\
\hline
\end{tabular}


TABLE III.- EXAMPLE PAGE FROM FMEA FOR IME MANIFOLDS

\begin{tabular}{|c|c|c|c|c|c|c|c|}
\hline $\begin{array}{r}\text { ID } \\
\text { NO. }\end{array}$ & $\begin{array}{c}\text { ITEM/ } \\
\text { FUNCTION }\end{array}$ & $\begin{array}{c}\text { FAIUUE } \\
\text { MODE }\end{array}$ & $\begin{array}{c}\text { FALURE } \\
\text { CAUSE }\end{array}$ & $\begin{array}{c}\text { FAILURE } \\
\text { EFFECT }\end{array}$ & $\begin{array}{l}\text { HAZ. } \\
\text { CAT. }\end{array}$ & $\begin{array}{c}\text { FAIL. } \\
\text { RATE } \\
/ 1000 \\
\text { FIR }\end{array}$ & $\begin{array}{c}\text { ACTION } \\
\text { REQ. }\end{array}$ \\
\hline 7.1 & $\begin{array}{l}\text { Oxidizer } \\
\text { Pump } \\
\text { Outlet Mani- } \\
\text { fold }\end{array}$ & $\begin{array}{l}7.1 .1 \text { Crack/fatigue } \\
7.1 .2 \text { Contamination } \\
\text { in ducting } \\
7.1 .3 \text { Flange distor- } \\
\text { tion } \\
7.1 .4 \text { Contamination } \\
\text { of seals/sealing sur- } \\
\text { face } \\
7.1 .5 \text { Seal failure } \\
7.1 .6 \text { Fastener torque } \\
\text { relaxation }\end{array}$ & $\begin{array}{l}\text { 7.1.1 Fatigue, vibra- } \\
\text { tion, thermal distor- } \\
\text { tion, material } \\
\text { defect, overstress, } \\
\text { improper machining, } \\
\text { weld anomaly } \\
7.1 .2 \text { External } \\
\text { source, manufactur- } \\
\text { ing } \\
7.1 .3 \text { Overpressure, } \\
\text { assembly error, ther- } \\
\text { mal } \\
7.1 .4 \text { External } \\
\text { source, manufactur- } \\
\text { ing } \\
7.1 .5 \text { Seal defect, } \\
\text { assembly error, } \\
\text { improper handling, } \\
\text { overstress, over- } \\
\text { temp., damage to } \\
\text { sealing surface } \\
7.1 .6 \text { Vibration, } \\
\text { excess. load. } \\
\text { improper assembly, } \\
\text { defect }\end{array}$ & $\begin{array}{l}\text { 7.1.1 Leakage of } \\
\text { oxidizer, fire, explo- } \\
\text { sion, loss of oxidizer } \\
\text { to chamber, loss of } \\
\text { performmce or mis- } \\
\text { sion } \\
7.1 .2 \text { Blockage of } \\
\text { passages leading to } \\
\text { reduced flow rates to } \\
\text { chamber } \\
7.1 .3 \text { same as } 7.1 .1 \\
7.1 .4 \text { same as } 7.1 .1 \\
7.1 .5 \text { same as } 7.1 .1 \\
7.1 .6 \text { same as } 7.1 .1\end{array}$ & $\begin{array}{l}\text { II } \\
\text { II } \\
\text { II } \\
\text { II }\end{array}$ & & $\begin{array}{l}\text { 7.1.1 Structural } \\
\text { proof testing; } \\
\text { safety factor of } 1.4 \\
7.1 .2 \text { Rigorous } \\
\text { inspection; con- } \\
\text { tamination con- } \\
\text { trol procedures } \\
7.1 .3 \text { Large } \\
\text { design margins; } \\
\text { leak checks prior } \\
\text { to start; rigorous } \\
\text { inspection } \\
7.1 .4 \text { Leak checks } \\
\text { prior to operation; } \\
\text { rigorous inspec- } \\
\text { tion; contamina- } \\
\text { tion control } \\
7.1 .5 \text { same as } \\
7.1 .3 \\
7.1 .6 \text { same } 2 \\
7.1 .3 \text { also self } \\
\text { locking nuts or } \\
\text { inserts }\end{array}$ \\
\hline
\end{tabular}

TABLE IV.- EXAMPLE PAGE FROM PHA FOR THE IME MANIFOLDS

\begin{tabular}{|c|c|c|c|c|c|c|c|}
\hline $\begin{array}{l}\text { ID } \\
\text { NO. }\end{array}$ & $\begin{array}{c}\text { HAZARD } \\
\text { CONDITION }\end{array}$ & $\begin{array}{l}\text { HAZARD } \\
\text { CAUSE(S) }\end{array}$ & $\begin{array}{l}\text { HAZARD } \\
\text { EFFECTS }\end{array}$ & $\begin{array}{l}\text { HAZ. } \\
\text { CAT. }\end{array}$ & $\begin{array}{l}\text { HAZ. } \\
\text { FREQ. }\end{array}$ & $\begin{array}{l}\text { HAZARD } \\
\text { CONTROLS }\end{array}$ & REMARKS \\
\hline 6.1 & Fire/Explosion & $\begin{array}{l}6.1 .1 \text { Leakage of } \\
\text { propellants from: } \\
\text { a: Crack/fatigue } \\
\text { b. Flange distortion } \\
\text { c. Contamination of } \\
\text { seal/sealing surface } \\
\text { d. Seal failure } \\
\text { e. Fastener torque } \\
\text { relaxation } \\
\text { (FMEA sections } \\
\text { 6.1-6.14,9.1,9.2) }\end{array}$ & $\begin{array}{l}\text { Leakage creates a } \\
\text { potentialy flamma- } \\
\text { ble environment; } \\
\text { instrumentation } \\
\text { may burn, prevent- } \\
\text { ing system health } \\
\text { monitoring: adja- } \\
\text { cent hardware may } \\
\text { overheal, leading to } \\
\text { cracksffailures; total } \\
\text { system loss }\end{array}$ & II & C & $\begin{array}{l}\text { Hardware designed } \\
\text { to safety factors of } \\
1.1 \text { in yield and } 1.4 \\
\text { in ultimate; contami- } \\
\text { nation control proce- } \\
\text { dures; stress analysis } \\
\text { of manifolds; leak } \\
\text { checks prior to oper- } \\
\text { ation; rigorous } \\
\text { inspection tech- } \\
\text { niques }\end{array}$ & Manifold \\
\hline & & $\begin{array}{l}6.1 .2 \text { Improper vent- } \\
\text { ing and routing of } \\
\text { propellants from: } \\
\text { a. Improper assem- } \\
\text { bly } \\
\text { b. Vent gases reenter } \\
\text { or collect in lines }\end{array}$ & $\begin{array}{l}\text { Mixing of oxidizer } \\
\text { and fuel may create } \\
\text { a potentially flam- } \\
\text { mable environment; } \\
\text { instrumentation } \\
\text { may burn, prevent- } \\
\text { ing system health } \\
\text { monitoring; adja- } \\
\text { cent hardware may } \\
\text { overheat, leading to } \\
\text { cracksfailures; total } \\
\text { system loss }\end{array}$ & II & $\mathbf{D}$ & $\begin{array}{l}\text { All oxidizer and } \\
\text { fuel lines will be } \\
\text { properly marked to } \\
\text { prevent improper } \\
\text { assembly; oxygen } \\
\text { turbopump interpro- } \\
\text { pellant seal assem- } \\
\text { bly vent line } \\
\text { pressures will be } \\
\text { monitored as redline }\end{array}$ & Manifold \\
\hline
\end{tabular}




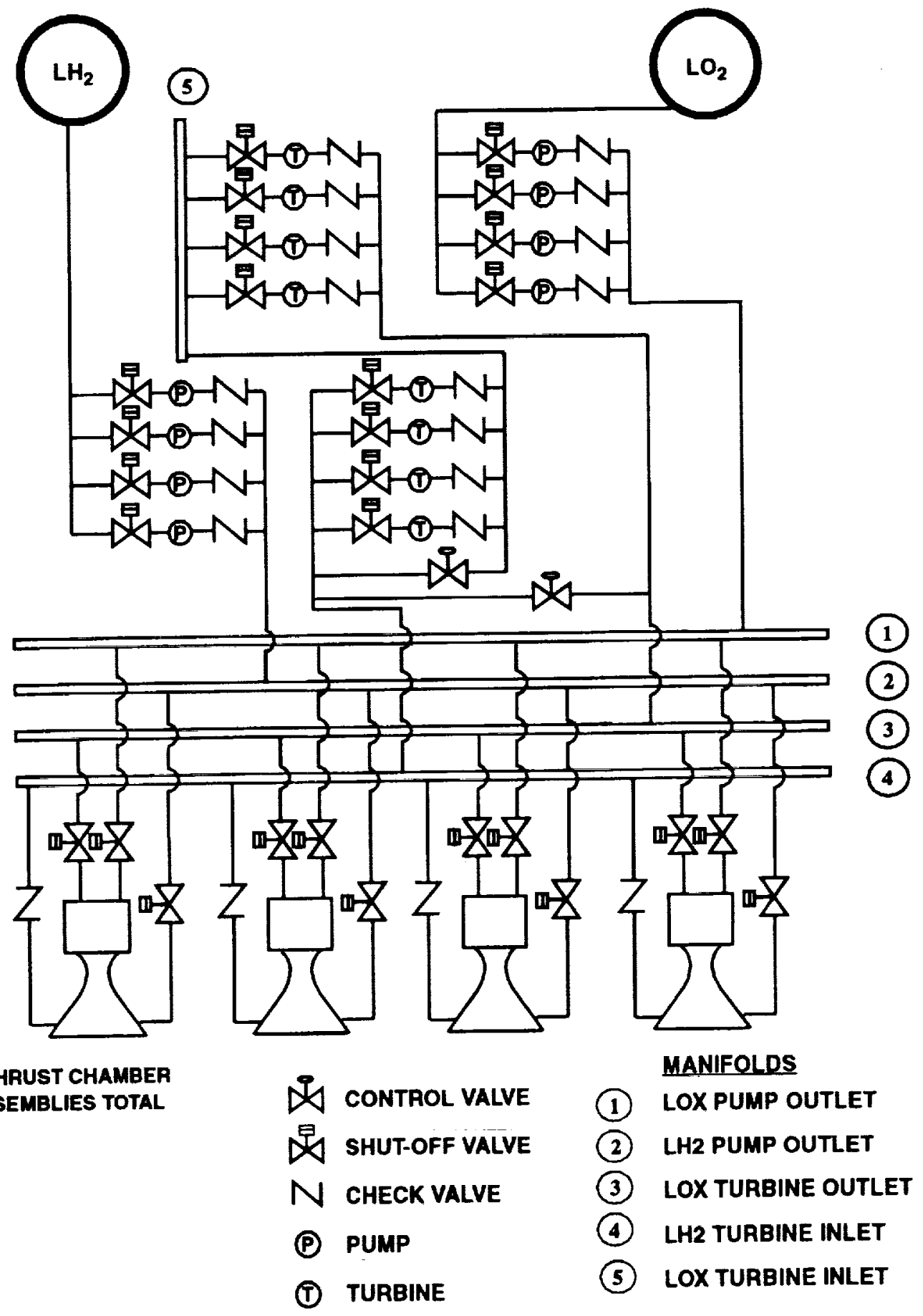

Figure 1.- IME schematic diagram, expander cycle configuration. 


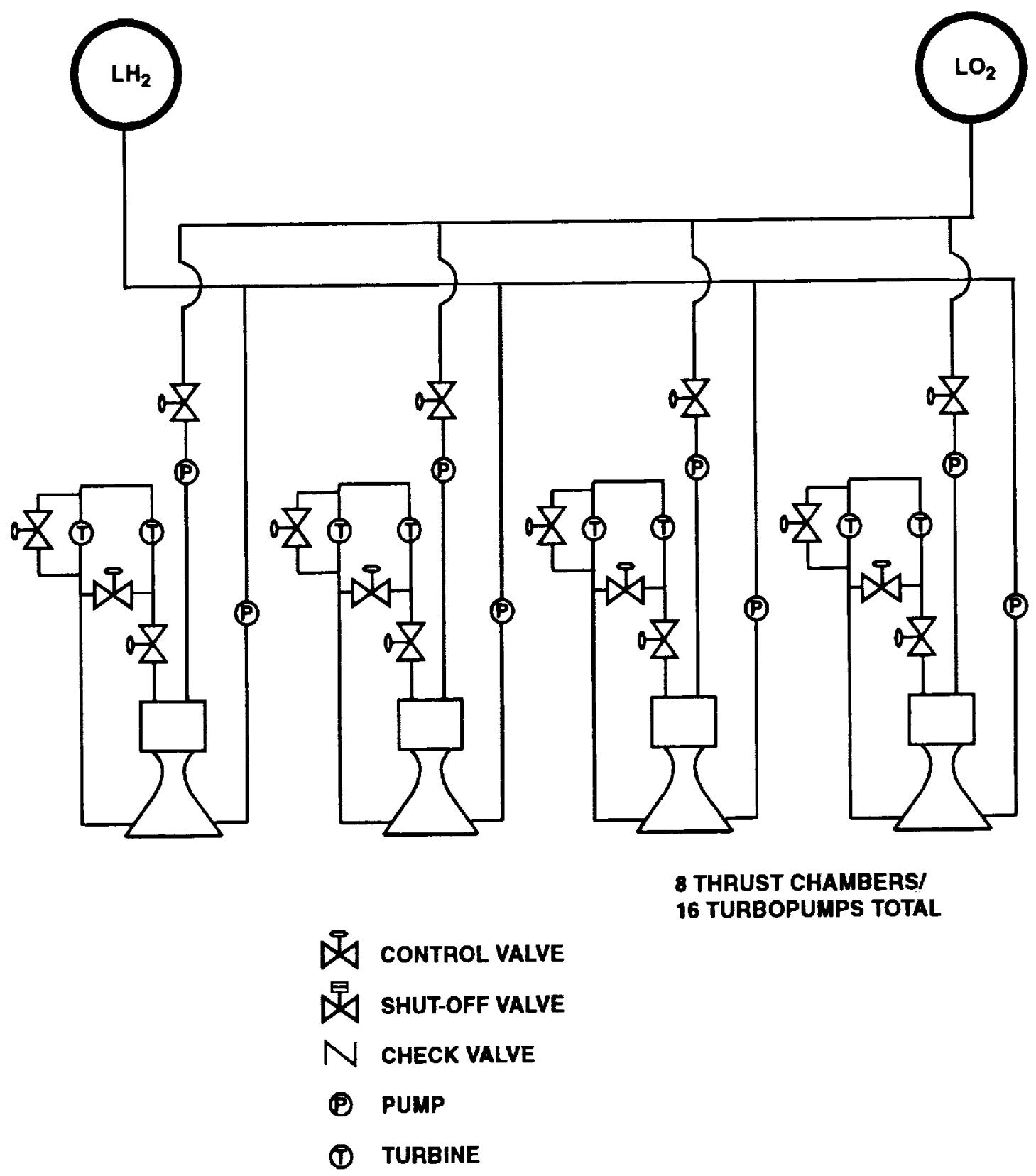

Figure 2.- Discrete engine schematic diagram, expander cycle configuration. 


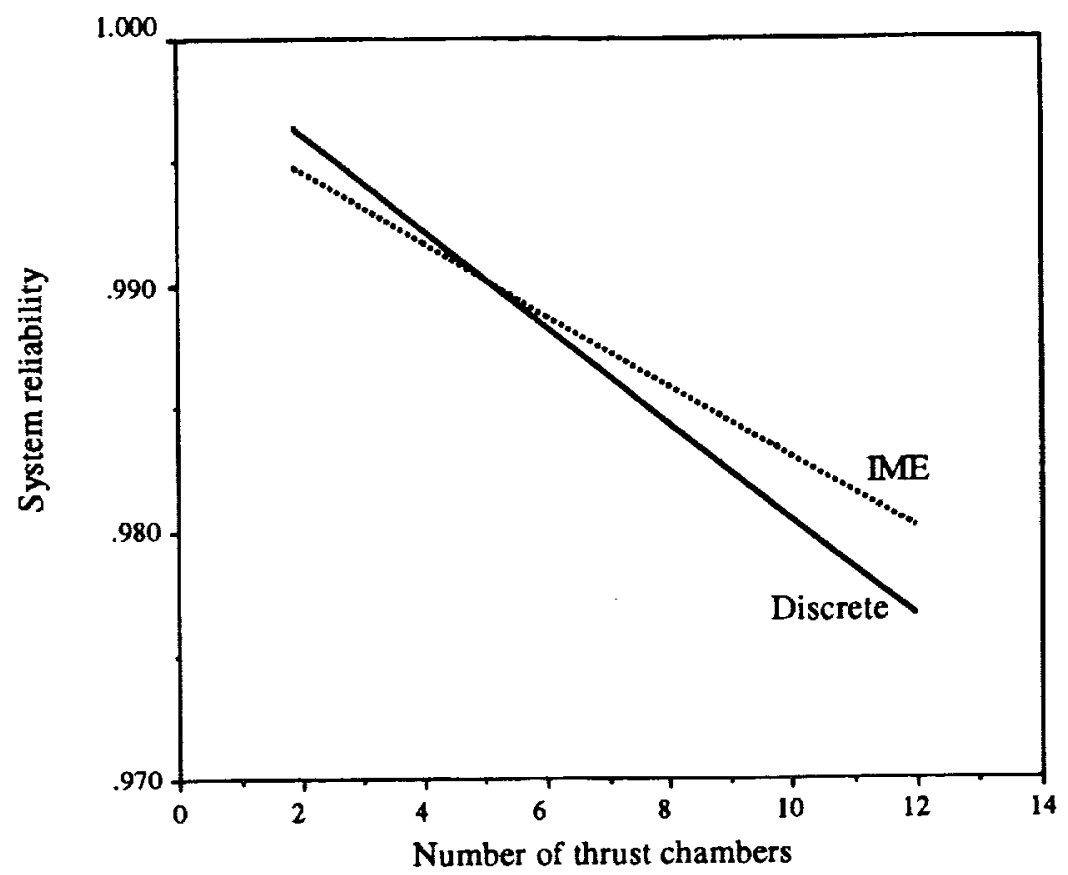

Figure 3.- Comparison of IME and discrete engine system reliability, no redundancy.

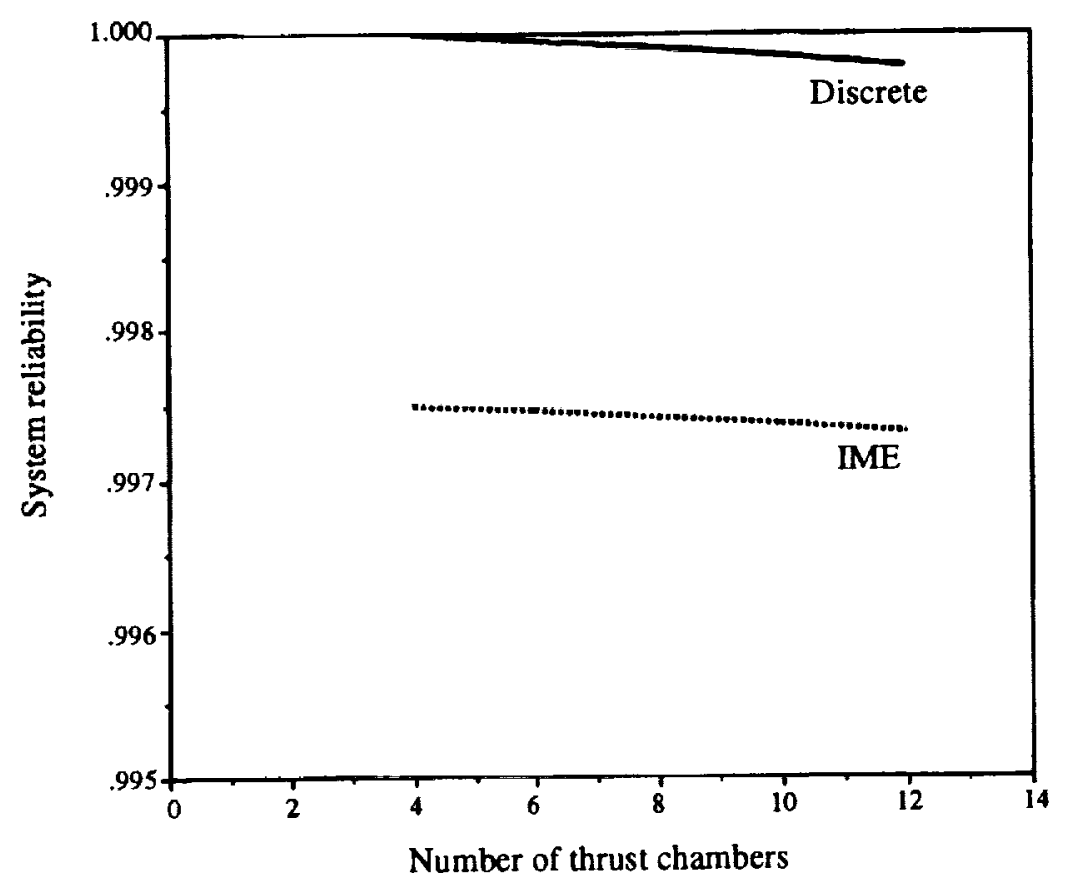

Figure 4.- Comparison of IME and discrete engine system reliability, one thrust chamber out, one turbopump out. 


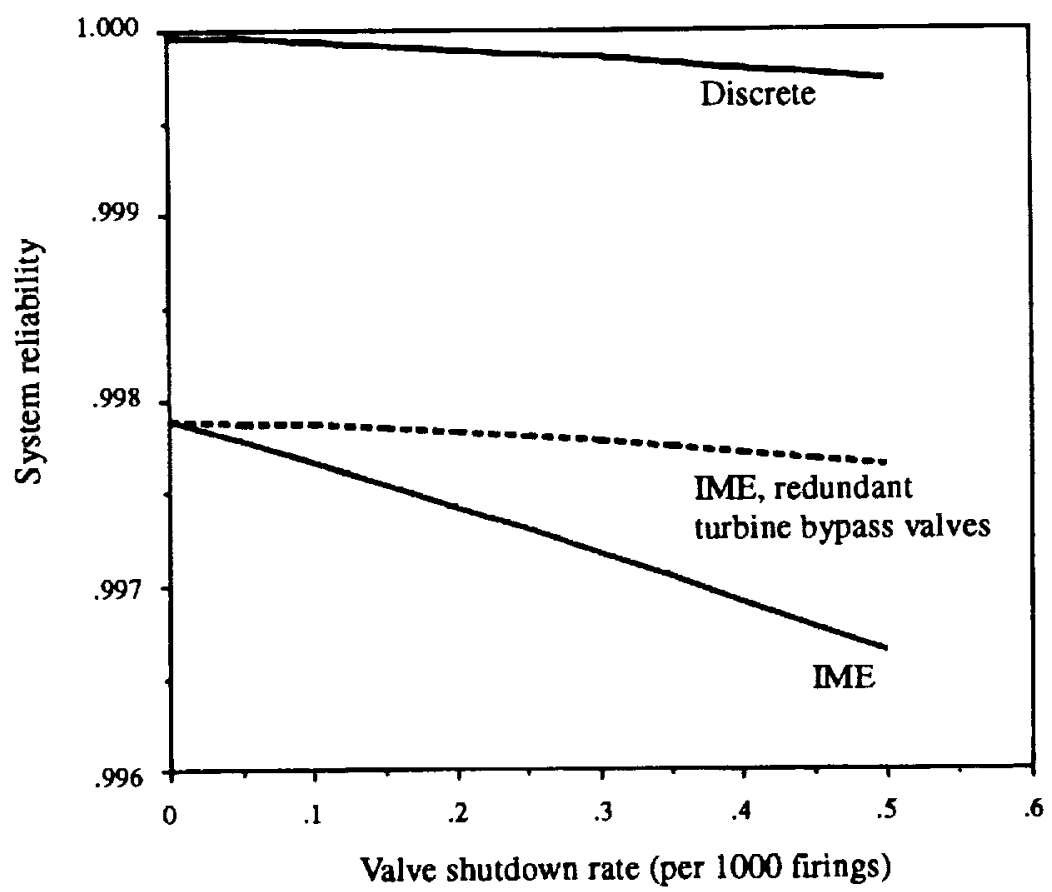

Figure 5.- Effect of valve shutdown rate on system reliability, one thrust chamber out, one turbopump out.

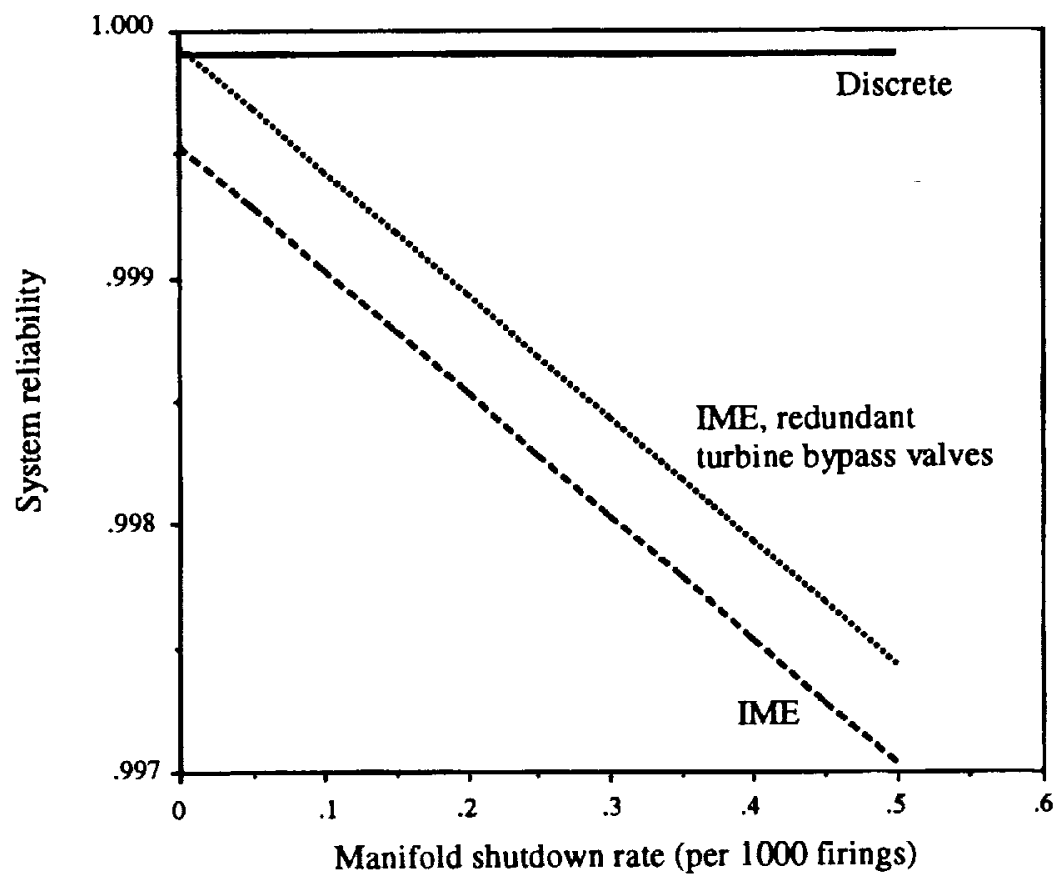

Figure 6.- Effect of manifold shutdown rate on system reliability, one thrust chamber out, one turbopump out. 


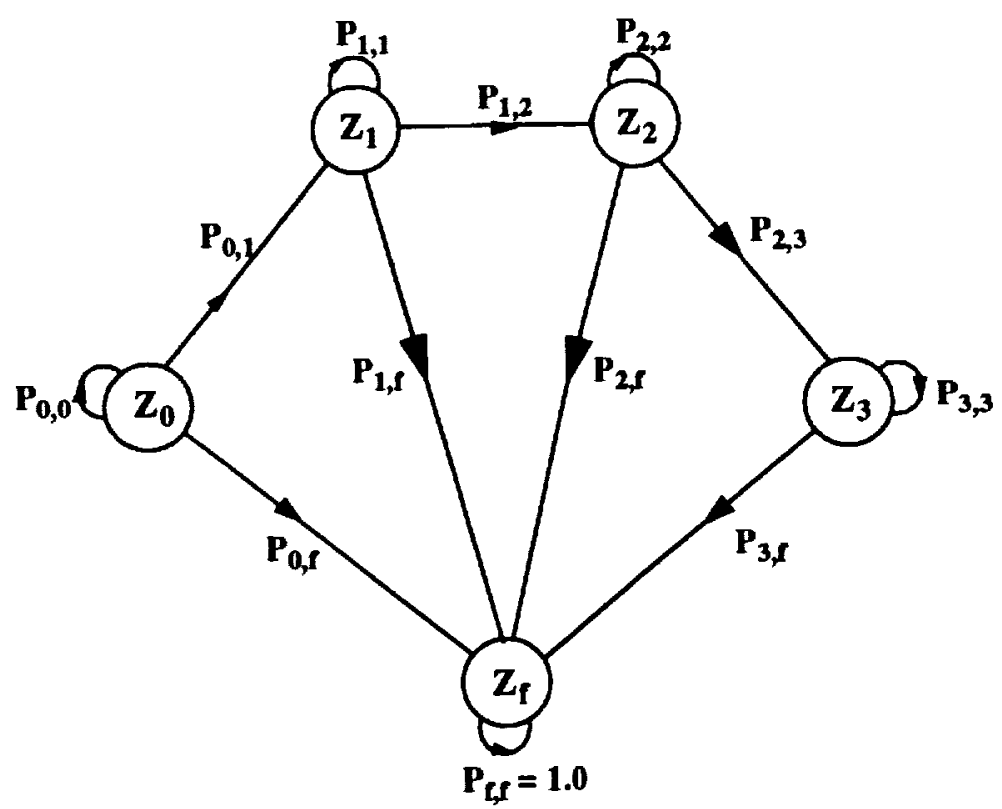

Figure 7.- Sample state space diagram.

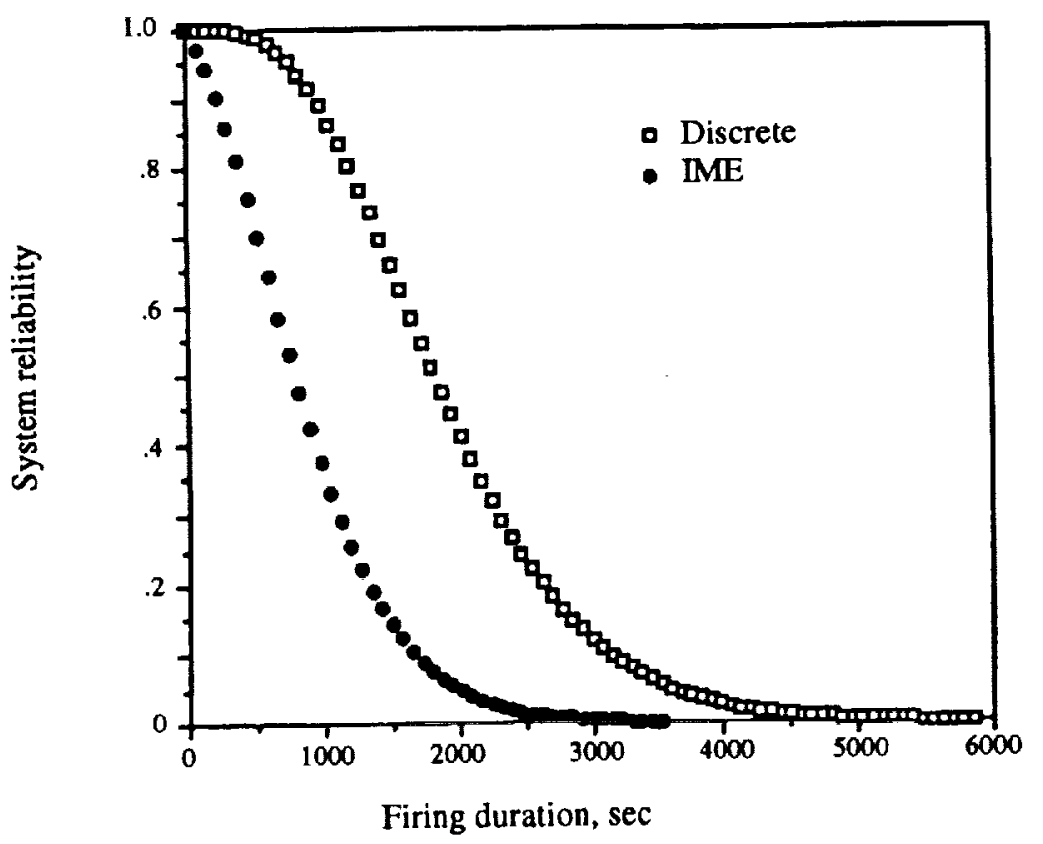

Figure 8.- Reliability comparison of discrete and IME concepts. 


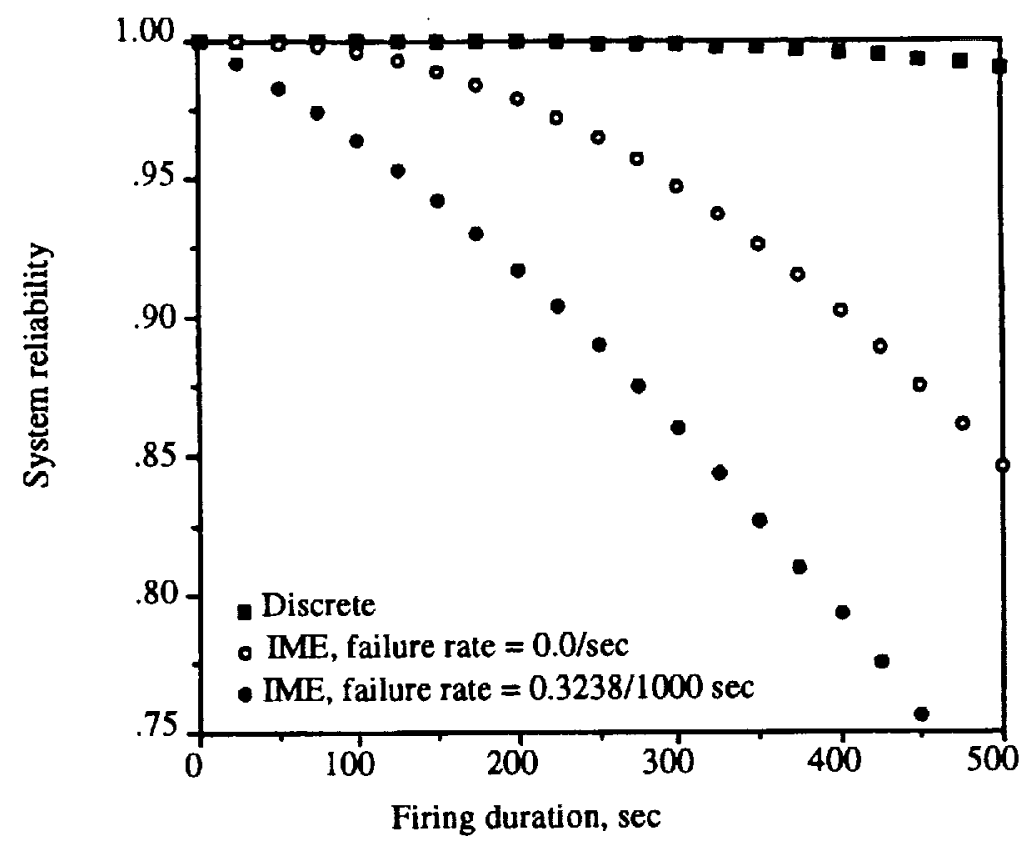

Figure 9.- Single-point failure effect on IME system reliability.

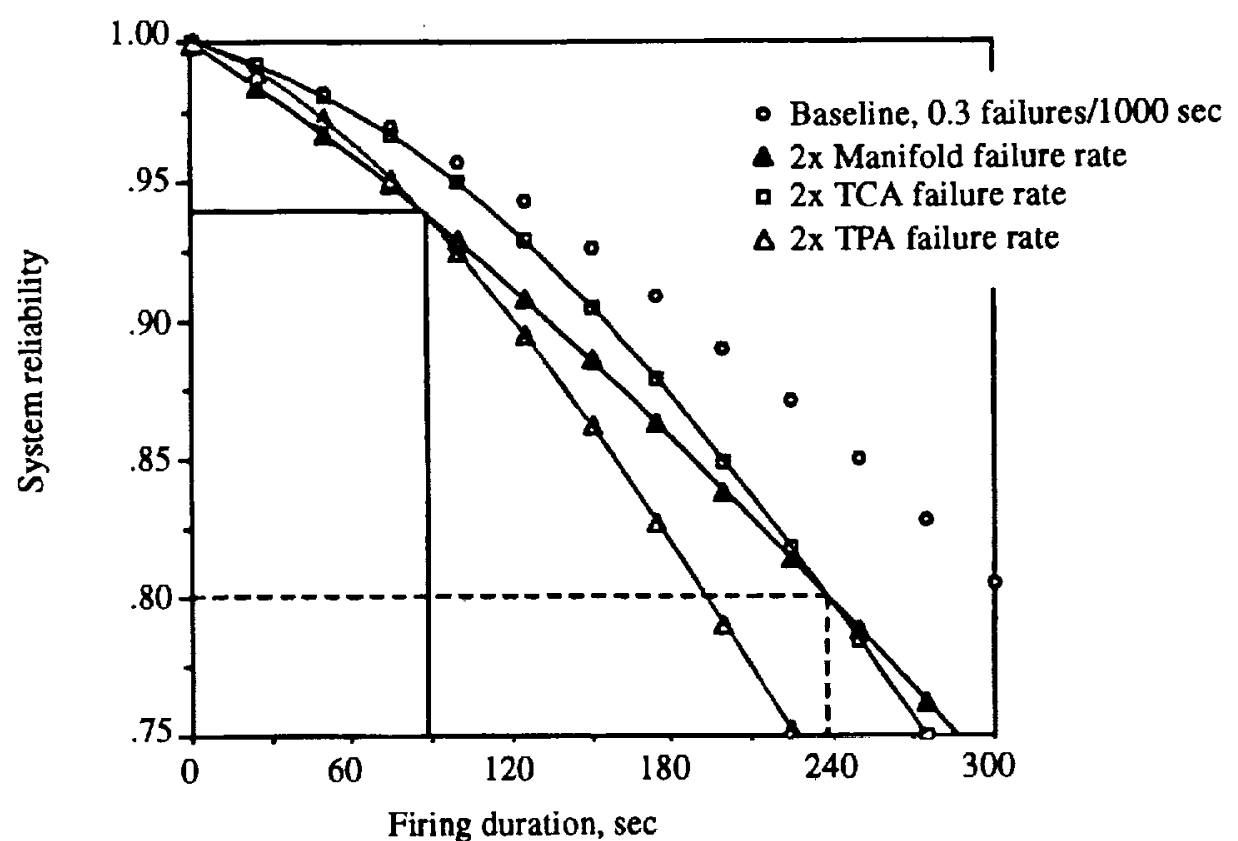

Figure 10. IME system reliability sensitivity to component failure rate. 


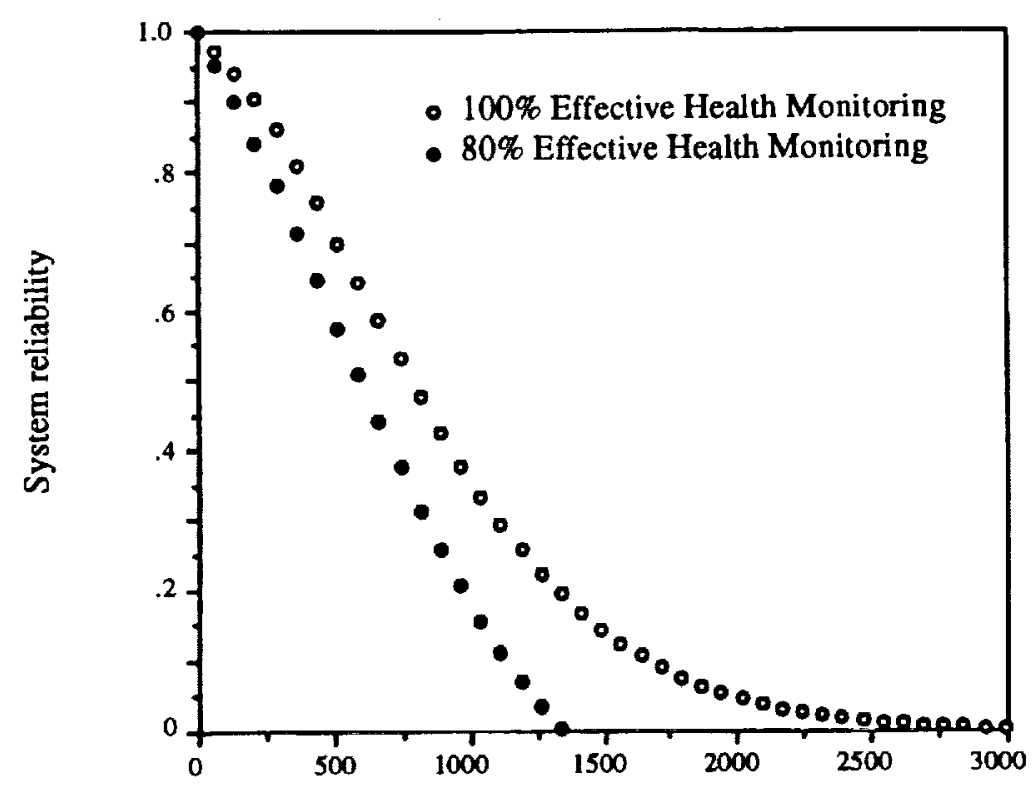

Firing duration, sec

Figure 11.- Health monitoring effect on IME system reliability.

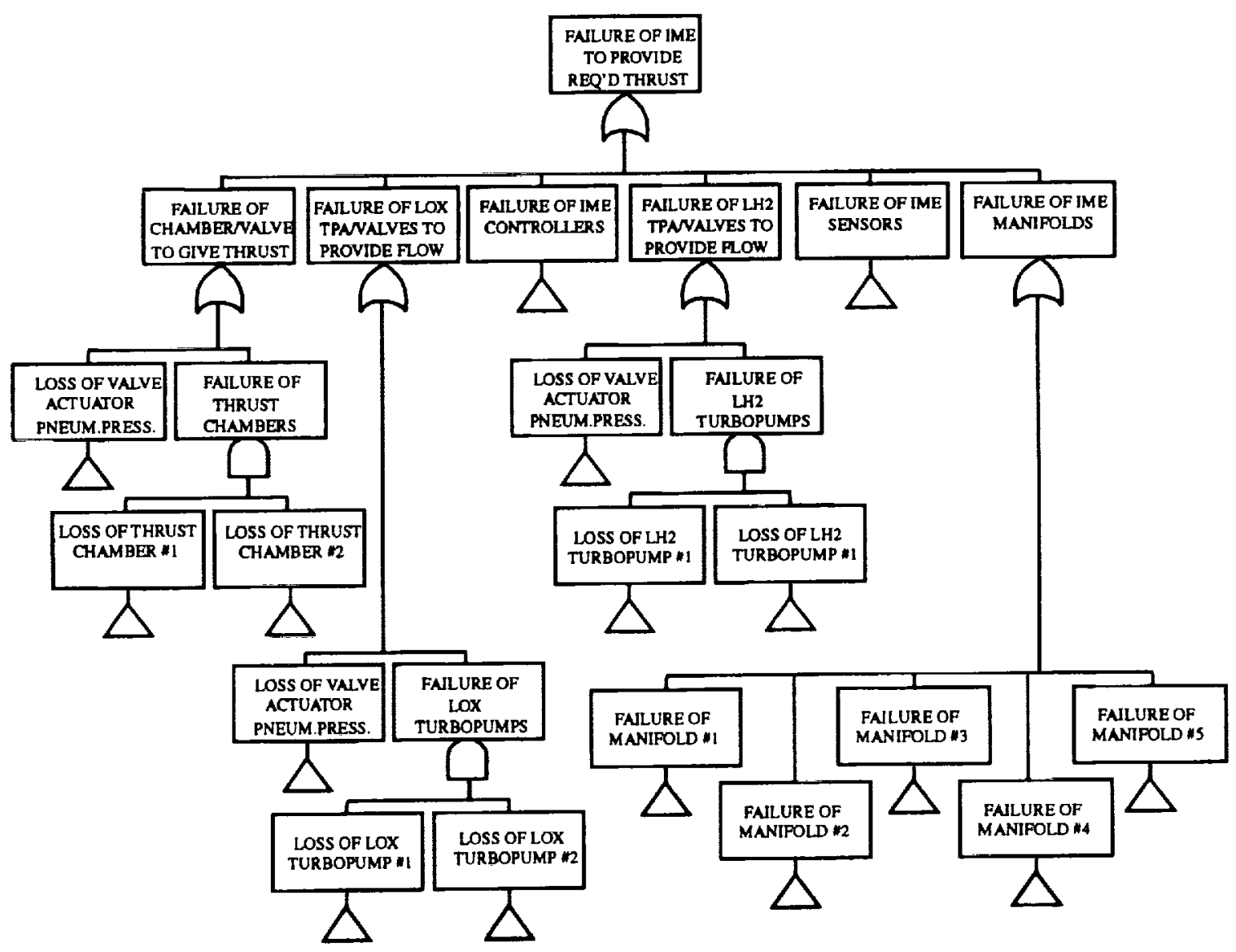

Figure 12.- Sample page from IME fault tree. 


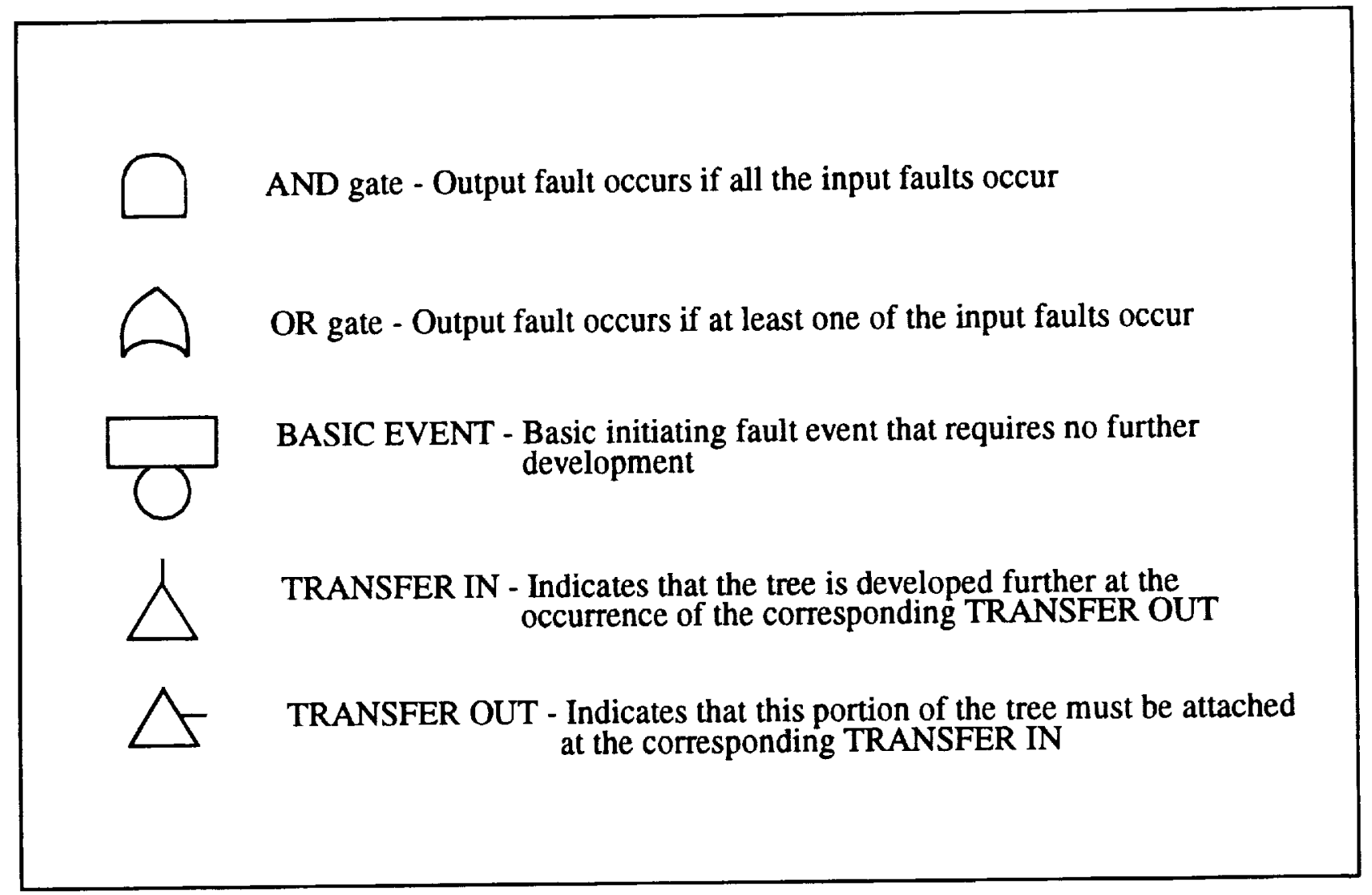

Figure 13.- Fault tree symbols. 
Public reponting burden tor this collection of intormation is estimated to average 1 hour per response, Including the time for reviewth instructions, searching existing data sources,

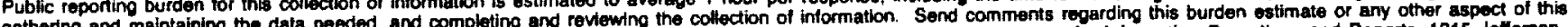
gathering and maintaining the dala needed, and completing and revewh Washington Headquarters Services, Directorate for Intormation Operations and Reports, 1215 Jefferson collection of intormation,

Davis Highway, Suhe 1204, ANingon, WA 22202-4302, and

\begin{tabular}{|l|c|c|}
\hline 1. AGENCY USE ONLY (Leave blank) & $\begin{array}{c}\text { 2. REPORT DATE } \\
\text { June } 1993\end{array}$ & $\begin{array}{r}\text { 3. AEPOAT TYPE AND DATES COVERED } \\
\text { Technical Memorandum }\end{array}$ \\
\hline
\end{tabular}

\section{TTLE AND SUBTTLE}

Reliability Studies of Integrated Modular Engine System Designs
5. FUNDING MUMBERS

WU-468-02-11

\section{AUTHOR(S)}

Terry L. Hardy and Douglas C. Rapp

\section{PERFORMING ORGANRATION NAME(S) AND ADDRESS(ES)}

National Aeronautics and Space Administration

Lewis Research Center

Cleveland, Ohio 44135-3191
- Performing organization REPORT NUMBER

E-7774
9. SPONSORINGMONTORING AGENCY NAME(S) AND ADDRESS(ES)

National Aeronautics and Space Administration

Washington, D.C. 20546-0001
10. SPONSORING MIONITORING AGENCY REPORT NUMBER

NASA TM-106178

AIAA-93-1886

\section{SUPPLEMENTARY NOTES}

Prepared for the 29th Joint Propulsion Conference and Exhibit cosponsored by the AIAA, SAE, ASME, and ASEE, Monterey, California, June 28-30, 1993. Terry L. Hardy, NASA Lewis Research Center and Douglas C. Rapp, Sverdrup Technologies, Inc. Lewis Research Center Group, 2001 Aerospace Parkway, Brook Park, Ohio 44142. Responsible person, Tenty L. Hardy, (216) 433-7517.

12. DISTALUUTION/AVAILABILTY STATEMENT

12b. DISTRIBUTION CODE

Unclassified - Unlimited

Subject Category 20

13. ABSTRACT (Maximum 200 worde)

A study was performed to evaluate the reliability of Integrated Modular Engine (IME) concepts. Comparisons were made between networked IME systems and non-networked discrete systems using expander cycle configurations. Both redundant and nonredundant systems were analyzed. Binomial approximation and Markov analysis techniques were employed to evaluate total system reliability. In addition, Failure Modes and Effects Analyses (FMEA), Preliminary Hazard Analyses (PHA), and Fault Tree Analysis (FTA) were performed to allow detailed evaluation of the IME concept. A discussion of these system reliability concepts is also presented.

14. SUBJECT TERMS

Rocket propulsion; Reliability; Risk assessment; Modularity

17. SECURIT CLASSIFICATION
OF REPORT
Unclassified

18. SECUATY CLASSIFICATION OF THIS PAGE

Unclassified
19. SECURTY CLASSIFICATION OF ABSTRACT Unclassified 